\title{
Effect of different nickel soil contents on cock's-foot yield and nitrogen, phosphorus and potassium contents
}

\author{
Wpływ zróżnicowanej ilości niklu w glebie na plon oraz \\ zawartość azotu, fosforu i potasu w kupkówce pospolitej
}

\begin{abstract}
* Dr hab. Beata Kuziemska, prof. nadzw., mgr Paulina Klej, mgr Joanna
Trębicka - Department of Soil and Agricultural Chemistry, Siedlce University

of Natural Science and Humanities, Prusa 14 St., 08-110 Siedlce,

e-mail:bak.kuz@interia.pl
\end{abstract}

Keywords: nickel, liming, organic material, cock's-foot, yield, macroelements

Słowa kluczowe: nikiel, wapnowanie, materiały organiczne, kupkówka pospolita, plon, makroelementy

\begin{abstract}
This study assessed the influence of liming and waste organic materials on the yield and nitrogen, phosphorus and potassium contents in cock's-foot (Dactylis glomerata L.) grown on nickelcontaminated soil in the third year of a pot culture experiment. In the experiment, the following factors were taken into consideration: (1) nickel soil contamination $\left(0,75,150\right.$ and $225 \mathrm{mg} \mathrm{Ni} \cdot \mathrm{kg}^{-1}$ of soil); (2) liming (0 Ca and $\mathrm{Ca}$ according to $1 \mathrm{Hh}$ of soil) and (3) organic materials (no waste organic materials added, brown coal from a coal mine in Turów and rye straw). Introducing nickel into the soil, regardless of its amount, caused a significant decrease in the total yield of cock's-foot and increased the nitrogen and potassium contents. Liming caused a significant increase in the yield of cock's-foot and decrease its potassium content, but it did not clearly differentiate the nitrogen and phosphorus content. The used organic materials (straw and brown coal) caused a decrease in the phosphorus content in the grass biomass.
\end{abstract}

๑) IOŚ-PIB

\section{INTRODUCTION}

The problem of soils and plants polluted by heavy metals is becoming increasingly important every year because their amount in the environment is systematically increasing [Kaszubkiewicz and Kawałko 2009, Ociepa and OciepaKubicka 2012]. The excessive concentration of these metals in soil has an adverse effect on the growth, yield and chemical composition of plants because of the bioaccumulation of heavy metals [Kobierski 2013]. This group of heavy metals includes nickel, which, on the one hand, is an essential element for the proper growth and development of plants but is toxic in greater concentrations. Amongst others, it forms part of the urease active site and it takes part in the metabolism of urea derivatives. Its deficiency in a plant leads to apical leaf necrosis and causes nickel accumulation in the cells [Wiechuła et al. 2012]. Nickel is a mobile element and its bioavailability to plants is high, particularly from nickel-contaminated soils. Nickel toxicity to plants results in, amongst others, chlorosis connected with excluding iron from physiological functions. An excess of nickel also inhibits iron-containing enzymes, for example, catalase and peroxidase,

\section{Streszczenie}

Celem pracy była ocena wpływu wapnowania oraz dodatku odpadowych materiałów organicznych na plonowanie oraz zawartość azotu, fosforu i potasu w kupkówce pospolitej (Dactylis gomerata L.) uprawianej na glebie zanieczyszczonej niklem w III roku doświadczenia wazonowego. W doświadczeniu uwzględniono następujące czynniki: 1. zanieczyszczenie gleb

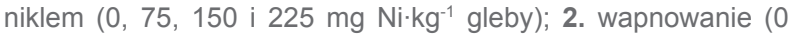
$\mathrm{Ca}$ i Ca wg $1 \mathrm{Hh}$ gleby); 3. materiały organiczne (bez dodatku odpadowych materiałów organicznych, węgiel brunatny z kopalni Turów i słoma żytnia). Wprowadzenie do gleby niklu, niezależnie od ilości spowodowało istotne zmniejszenie plonu sumarycznego kupkówki pospolitej oraz zwiększenie w niej zawartości azotu i potasu. Zastosowanie zabiegu wapnowania spowodowało istotne zwiększenie plonu kupkówki pospolitej oraz zmniejszenie w niej ilości potasu, nie różnicując jednoznacznie zawartości azotu i fosforu. Zastosowane materiały organiczne (słoma i węgiel brunatny) spowodowały zmniejszenie zawartości fosforu w biomasie trawy.

and when it exceeds a critical concentration, it also disturbs photosynthesis because of its influence on electron transport and causes a decrease in chlorophyll [Boyd and Davis 2001; Sheoran et al. 1990].

This study assessed the influence of liming and adding selected organic materials on the yield and contents of nitrogen, phosphorus and potassium in cock's-foot (Dactylis glomerata L.) grown on soil contaminated with nickel in the third year of a pot culture experiment.

\section{MATERIALS AND METHODS}

A pot culture experiment was carried out in the experimental facilities of the University of Natural Sciences and Humanities in Siedlce from 2008 to 2011 using a completely randomised design in four repetitions, with the following factors considered:

1. Soil contamination with nickel (in the form of an aqueous solution $\mathrm{NiSO}_{4} \cdot 7 \mathrm{H}_{2} \mathrm{O}$ ): $0 \mathrm{Ni}$ (without using nickel); $75 \mathrm{mg} \mathrm{Ni} \cdot \mathrm{kg}^{-1}$ of soil; $150 \mathrm{mg} \mathrm{Ni} \cdot \mathrm{kg}^{-1}$ of soil; $225 \mathrm{mg} \mathrm{Ni} \cdot \mathrm{kg}^{-1}$ of soil. 
Table 1. Chemical composition of organic materials used in pot experiment

\begin{tabular}{|c|c|c|c|}
\hline Component & Content & Rye straw & \multicolumn{2}{c|}{ Lignite } \\
\hline Dry matter & & 850 & 850 \\
\hline C & & 432 & 541 \\
\hline N & & 4.22 & 4.00 \\
\hline P & \multirow{2}{*}{$\cdot k^{-1}$ dry matter } & 0.64 & 0.11 \\
\hline $\mathrm{K}$ & & 2.00 & 0.84 \\
\hline $\mathrm{Ni}$ & $\mathrm{mg} \cdot \mathrm{kg}^{-1}$ dry matter & 3.84 & 5.10 \\
\hline
\end{tabular}

2. Liming (in the form of $\mathrm{CaCO}_{3}$ ): $0 \mathrm{Ca}$ (no liming); $\mathrm{Ca}$ according to $1 \mathrm{Hh}$ (liming with a dose calculated according to 1 soil hydrolytic acidity).

3. Waste organic materials: no organic materials added (0); brown coal from the coal mine in Turów in a dose of $40 \mathrm{t} \cdot \mathrm{ha}^{-1}\left(13.3 \mathrm{~g} \cdot \mathrm{kg}^{-1}\right.$ of soil); rye straw in a dose of $4 \mathrm{t} \cdot \mathrm{ha}^{-1}$

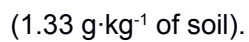

Liming, addition of waste organic material (brown coal and straw cut into chaff) and nickel were used in November 2008. Cock'sfoot (D. glomerata L.) sown in the spring of 2009 was placed into $15 \mathrm{dm}^{3}$ pots containing $10 \mathrm{~kg}$ of the soil material. In each vegetation season, four cuts of the cock's-foot were harvested (with the cock's-foot growing back every 30 days). In this way, the plants from all the cuts harvested in the third year of the experiment were analysed. The soil formation used in the experiment was taken from a $0-20 \mathrm{~cm}$ soil layer of Albic Luvisol with a granulometric composition of loamy sand and the following properties: $\mathrm{pH}$ in a $1 \mathrm{M} \mathrm{KCl}$ solution is 5.5 ; macroelement contents: total nitrogen is $0.98 \mathrm{~g}^{\mathrm{kg}}{ }^{-1}$ of soil, organic carbon is 7.9 $\mathrm{g} \cdot \mathrm{kg}^{-1}$ of soil, available phosphorus is $69 \mathrm{mg} \cdot \mathrm{kg}^{-1}$ of soil, available potassium is $75 \mathrm{mg} \cdot \mathrm{kg}^{-1}$ of soil. The total nickel content in the soil was $5.67 \mathrm{mg} \mathrm{Ni} \cdot \mathrm{kg}^{-1}$ of soil. The chemical composition of the used organic materials is presented in Table 1.

The pots were placed in the open air, under shelter with humidity maintained at the level of $60 \%$ of the maximum water holding capacity. The nitrogen content in plants was determined with the elemental analysis method, using a $\mathrm{CHN}$ autoanalyser with a thermal conductivity detector (IDC), Series II 2400 , produced by Perkin Elmer. The phosphorus and potassium contents were determined with the inductively coupled plasma atomic emission spectrometry method, using an Optima 3200RL apparatus produced by Perkin Elmer. Before the determination, the material was subjected to dry ashing in a muffle furnace at $450{ }^{\circ} \mathrm{C}$ and the ash was dissolved in a $10 \% \mathrm{HCl}$ solution. The research results were statistically analysed with analysis of variance using the Fisher-Snedecor distribution, with STATISTICA 10PI (STATSOFT, TULSA, USA) software, and the $\operatorname{LSD}_{(0.05)}$ value was calculated according to Tukey's range test.

\section{RESULTS AND DISCUSSION}

The influence of the factors tested in the experiment on the yield and the chemical composition of cock's-foot in the first two years of the pot culture experiment was presented in previous studies
[Kalembasa et al. 2014, Kuziemska et al. 2014]. The results presented in the current study concern the influence of liming and the use of diverse organic materials (rye straw and brown coal from the coal mine in Turów) on the yield and nitrogen, phosphorus and potassium contents in the biomass of cock'sfoot grown on soil contaminated to various degrees with nickel in the third year of the experiment.

The yield of the successive cuts of the test plant (Table 2) was shaped by differences in the nickel soil content and soil $\mathrm{pH}$ (liming).

The greatest average yield was harvested in the first cut $\left(4.26 \mathrm{~g} \mathrm{s.m.} \cdot\right.$ pot $\left.^{-1}\right)$ and the smallest was in the fourth cut $\left(0.93 \mathrm{~g} \mathrm{s.m}\right.$. pot $\left.{ }^{-1}\right)$. With the increase in the nickel soil content, the yield size decreased for all grass cuts. For the first cut, significant differences were reported for the highest dose $\left(225 \mathrm{mg} \mathrm{Ni} \cdot \mathrm{kg}^{-1}\right.$ of soil), whilst for the other cuts, significant differences were noted for all experimental nickel doses. Similar results were also found for total yield. The introduction of increasing amounts of nickel to the soil caused a decrease in the total yield of cock's-foot by $4 \%, 4 \%, 7 \%, 4 \%$ and $30.4 \%$, respectively, compared to the yield harvested from the control object. The negative influence of nickel soil contamination on the yields of various plant species was also found by other authors [Molas 2000, Spiak et al.2003]. The applied liming caused a significant yield increase for all test plant cuts and a total yield increase of $43 \%$, which may be connected with immobilising nickel in soil and lowering its bioavailability. In the conducted studies, no significant influence of the used organic materials on the discussed property was found. However, the total yield harvested from the objects where the materials were used was smaller than that obtained from the control object.

Under the experimental conditions, the average nitrogen content in the grass biomass varied from 21.1 to $26.3 \mathrm{~g} \cdot \mathrm{kg}^{-1}$ of dry mass and it depended not only on the factors tested in the study but also on the harvest date (Table 3).

The highest average concentration of nitrogen was found in plants harvested in the first cut $\left(25.3 \mathrm{~g} \cdot \mathrm{kg}^{-1}\right.$ of dry mass $)$ and the lowest was in the plants harvested in the third cut (22.9 $\mathrm{g} \cdot \mathrm{kg}^{-1}$ of dry mass). A decrease in the nitrogen content in the grass each time it grew back was also found by Nogalska and Czapla [2011]. The influence of different nickel soil contents on the nitrogen content was found only in plants harvested in the first two cuts. The nitrogen content in cock's-foot biomass increased significantly along with an increase in the nickel contamination of the soil. No significant influence of liming or organic materials on 
Table 2. Yield of biomass of cock's-foot in $\mathrm{g} \cdot \mathrm{pot}^{-1}$

\begin{tabular}{|c|c|c|c|c|c|c|c|}
\hline \multirow{2}{*}{ Liming } & \multirow{2}{*}{$\begin{array}{c}\text { Organic } \\
\text { fertilisation }\end{array}$} & \multirow{2}{*}{$\begin{array}{l}\text { Doses of nickel } \\
\text { ( } \mathrm{mg} \cdot \mathrm{kg}^{-1} \text { of soil) }\end{array}$} & \multicolumn{4}{|c|}{ Cut } & \multirow{2}{*}{ Sum } \\
\hline & & & I & II & III & IV & \\
\hline \multirow{3}{*}{ Without liming } & Without organic fertilisation & $\begin{array}{c}0 \\
75 \\
150 \\
225\end{array}$ & $\begin{array}{l}5.07 \\
3.93 \\
3.53 \\
0.90\end{array}$ & $\begin{array}{l}1.91 \\
1.94 \\
1.62 \\
0.64\end{array}$ & $\begin{array}{l}2.47 \\
1.69 \\
1.37 \\
0.34\end{array}$ & $\begin{array}{l}1.10 \\
0.87 \\
0.70 \\
0.40\end{array}$ & $\begin{array}{c}10.55 \\
8.43 \\
7.23 \\
2.23\end{array}$ \\
\hline & Rye straw & $\begin{array}{c}0 \\
75 \\
150 \\
225\end{array}$ & $\begin{array}{l}4.07 \\
4.47 \\
5.73 \\
1.33\end{array}$ & $\begin{array}{l}2.35 \\
1.39 \\
1.59 \\
1.35\end{array}$ & $\begin{array}{l}1.89 \\
1.49 \\
1.33 \\
0.35\end{array}$ & $\begin{array}{l}0.97 \\
0.87 \\
1.03 \\
0.50\end{array}$ & $\begin{array}{l}9.25 \\
8.21 \\
9.69 \\
3.58\end{array}$ \\
\hline & Brown coal & $\begin{array}{c}0 \\
75 \\
150 \\
225\end{array}$ & $\begin{array}{l}4.90 \\
4.03 \\
2.07 \\
2.03\end{array}$ & $\begin{array}{l}2.89 \\
1.69 \\
2.67 \\
1.48\end{array}$ & $\begin{array}{l}1.85 \\
1.46 \\
0.91 \\
0.38\end{array}$ & $\begin{array}{l}1.13 \\
1.03 \\
0.70 \\
1.00\end{array}$ & $\begin{array}{c}10.74 \\
8.21 \\
6.34 \\
4.89\end{array}$ \\
\hline \multirow{3}{*}{$\begin{array}{l}\text { Liming according } \\
\text { to } 1 \mathrm{Hh} \text { of soil }\end{array}$} & Without organic fertilisation & $\begin{array}{c}0 \\
75 \\
150 \\
225\end{array}$ & $\begin{array}{l}5.23 \\
5.20 \\
6.27 \\
4.77\end{array}$ & $\begin{array}{l}3.32 \\
2.44 \\
3.65 \\
3.05\end{array}$ & $\begin{array}{l}1.75 \\
1.59 \\
1.88 \\
2.25\end{array}$ & $\begin{array}{l}0.50 \\
1.40 \\
1.27 \\
1.50\end{array}$ & $\begin{array}{l}10.80 \\
10.62 \\
13.06 \\
11.57\end{array}$ \\
\hline & Rye straw & $\begin{array}{c}0 \\
75 \\
150 \\
225\end{array}$ & $\begin{array}{l}4.37 \\
4.17 \\
3.63 \\
5.80\end{array}$ & $\begin{array}{l}2.50 \\
4.05 \\
2.39 \\
2.57\end{array}$ & $\begin{array}{l}1.47 \\
1.49 \\
1.50 \\
1.97\end{array}$ & $\begin{array}{l}1.07 \\
0.80 \\
1.00 \\
1.00\end{array}$ & $\begin{array}{c}9.40 \\
10.51 \\
8.52 \\
11.33\end{array}$ \\
\hline & Brown coal & $\begin{array}{c}0 \\
75 \\
150 \\
225\end{array}$ & $\begin{array}{l}3.83 \\
6.50 \\
6.16 \\
4.37\end{array}$ & $\begin{array}{l}2.98 \\
2.36 \\
2.75 \\
1.72\end{array}$ & $\begin{array}{l}2.00 \\
2.13 \\
1.99 \\
1.58\end{array}$ & $\begin{array}{l}1.07 \\
1.03 \\
0.50 \\
1.00\end{array}$ & $\begin{array}{c}11.88 \\
12.03 \\
11.37 \\
8.66\end{array}$ \\
\hline \multicolumn{2}{|c|}{ Mean for liming } & $\begin{array}{c}\text { Without liming } \\
\text { Liming according to } 1 \\
\text { Hh of soil }\end{array}$ & $\begin{array}{l}3.51 \\
5.02\end{array}$ & $\begin{array}{l}1.79 \\
2.81\end{array}$ & $\begin{array}{l}1.29 \\
1.80\end{array}$ & $\begin{array}{l}0.85 \\
1.01\end{array}$ & $\begin{array}{c}7.44 \\
10.64\end{array}$ \\
\hline \multicolumn{2}{|c|}{ Mean for organic fertilisation } & $\begin{array}{c}\text { Without organic fertili- } \\
\text { sation } \\
\text { Rye straw } \\
\text { Brown coal }\end{array}$ & $\begin{array}{l}4.36 \\
4.20 \\
4.24\end{array}$ & $\begin{array}{l}2.32 \\
2.27 \\
2.32\end{array}$ & $\begin{array}{l}1.67 \\
1.43 \\
1.54\end{array}$ & $\begin{array}{l}0.97 \\
0.90 \\
0.93\end{array}$ & $\begin{array}{l}9.32 \\
8.80 \\
9.03\end{array}$ \\
\hline \multicolumn{2}{|c|}{ Mean for doses of nickel } & $\begin{array}{c}0 \\
75 \\
150 \\
225\end{array}$ & $\begin{array}{l}4.58 \\
4.72 \\
4.56 \\
3.20\end{array}$ & $\begin{array}{l}2.66 \\
2.31 \\
2.43 \\
1.80\end{array}$ & $\begin{array}{l}1.90 \\
1.64 \\
1.50 \\
1.14\end{array}$ & $\begin{array}{l}0.97 \\
1.00 \\
0.87 \\
0.90\end{array}$ & $\begin{array}{l}10.11 \\
9.67 \\
9.36 \\
7.04\end{array}$ \\
\hline \multicolumn{3}{|c|}{ Mean for experiment } & 4.26 & 2.30 & 1.55 & 0.93 & 9.04 \\
\hline \multicolumn{3}{|c|}{$\begin{array}{c}\text { LSD }_{0.05} \text { for: } \\
\text { Doses of nickel: } \\
\text { Liming: } \\
\text { Organic fertilisation: }\end{array}$} & $\begin{array}{c}\text { I cut } \\
0.912 \\
0.487 \\
\text { n.s. }\end{array}$ & $\begin{array}{c}\text { II cut } \\
0.369 \\
0.197 \\
\text { n.s. }\end{array}$ & $\begin{array}{c}\text { III cut } \\
0.296 \\
0.158 \\
\text { n.s. }\end{array}$ & $\begin{array}{l}\text { IV cut Sum } \\
0.1321 .071 \\
0.0710 .572 \\
\text { n.s. n.s. }\end{array}$ & \\
\hline
\end{tabular}

Explanations: n.s. - no signified

the nitrogen content in the test plants was found. No influence of the applied organic materials on the nitrogen content in the plants was found either. It should be noted that even though the straw (containing $4.22 \mathrm{~g} \mathrm{~N} \cdot \mathrm{kg}^{-1}$ of d. m.) and the brown coal (containing $4.00 \mathrm{~g} \mathrm{~N} \cdot \mathrm{kg}^{-1}$ of $\mathrm{d}$. $\mathrm{m}$.) were used four years earlier, the nitrogen content in the plants grown on the objects enriched in these materials was still higher than in the control plants (on an average by $4.7 \%$ for the straw and $3.9 \%$ for the brown coal).

The phosphorus content in cock's-foot was differentiated by the nickel soil content, the organic materials used and the harvest date (Table 4).
The greatest average phosphorus content was determined in the biomass of the plants harvested in the fourth cut $\left(3.36 \mathrm{~g} \mathrm{P}^{\mathrm{kg}} \mathrm{kg}^{-1}\right.$ of dry mass) and the lowest was in the biomass of the plants harvested in the first cut $\left(2.75 \mathrm{~g} \mathrm{P} \cdot \mathrm{kg}^{-1}\right.$ of dry mass).

As according to Falkowski et al. [2000] grasses should contain from $0.28 \%$ to $0.35 \% \mathrm{P}$ in their dry mass, the determined phosphorus content fits within the optimal range. The influence of different nickel soil contents on the phosphorus content was not clear and it depended on the harvest date. In the plants harvested in the first cut, nickel introduced into soil in doses of 75 and $150 \mathrm{mg} \mathrm{Ni} \cdot \mathrm{kg}^{-1}$ of soil caused significant increases in phosphorus content (by $16.8 \%$ and $14 \%$, respectively), whilst 
Table 3. Nitrogen content ( $\mathrm{g} \cdot \mathrm{kg}^{-1} \mathrm{~d} . \mathrm{m}$.) in cock's-foot biomass

\begin{tabular}{|c|c|c|c|c|c|c|c|}
\hline \multirow{2}{*}{ Liming } & \multirow{2}{*}{$\begin{array}{c}\text { Organic } \\
\text { fertilisation }\end{array}$} & \multirow{2}{*}{$\begin{array}{l}\text { Doses of nickel } \\
\left(\mathrm{mg} \cdot \mathrm{kg}^{-1} \text { of soil) }\right.\end{array}$} & \multicolumn{4}{|c|}{ Cut } & \multirow{2}{*}{ Mean } \\
\hline & & & I & II & III & IV & \\
\hline \multirow{3}{*}{$\begin{array}{l}\text { Without } \\
\text { liming }\end{array}$} & $\begin{array}{l}\text { Without } \\
\text { organic } \\
\text { fertilisation }\end{array}$ & $\begin{array}{c}0 \\
75 \\
150 \\
225\end{array}$ & $\begin{array}{l}20.9 \\
23.4 \\
25.6 \\
24.5\end{array}$ & $\begin{array}{l}20.6 \\
22.4 \\
24.0 \\
24.5\end{array}$ & $\begin{array}{l}21.6 \\
22.6 \\
22.3 \\
22.4\end{array}$ & $\begin{array}{l}21.5 \\
22.2 \\
22.8 \\
22.5\end{array}$ & $\begin{array}{l}21.1 \\
22.6 \\
23.7 \\
23.5\end{array}$ \\
\hline & Rye straw & $\begin{array}{c}0 \\
75 \\
150 \\
225\end{array}$ & $\begin{array}{l}23.0 \\
24.6 \\
27.0 \\
30.1\end{array}$ & $\begin{array}{l}21.9 \\
23.1 \\
24.2 \\
30.1\end{array}$ & $\begin{array}{l}22.5 \\
23.9 \\
23.9 \\
21.8\end{array}$ & $\begin{array}{l}22.5 \\
23.5 \\
23.6 \\
23.4\end{array}$ & $\begin{array}{l}22.5 \\
23.8 \\
24.7 \\
26.3\end{array}$ \\
\hline & Brown coal & $\begin{array}{c}0 \\
75 \\
150 \\
225\end{array}$ & $\begin{array}{l}22.1 \\
23.5 \\
27.0 \\
28.5\end{array}$ & $\begin{array}{l}22.4 \\
22.7 \\
25.4 \\
28.5\end{array}$ & $\begin{array}{l}22.3 \\
24.2 \\
23.0 \\
22.6\end{array}$ & $\begin{array}{l}23.1 \\
22.7 \\
24.1 \\
22.2\end{array}$ & $\begin{array}{l}22.2 \\
23.3 \\
24.9 \\
25.4\end{array}$ \\
\hline \multirow{3}{*}{$\begin{array}{l}\text { Liming according to } 1 \\
\text { Hh of soil }\end{array}$} & $\begin{array}{l}\text { Without } \\
\text { organic } \\
\text { fertilisation }\end{array}$ & $\begin{array}{c}0 \\
75 \\
150 \\
225\end{array}$ & $\begin{array}{l}24.9 \\
24.9 \\
26.1 \\
25.0\end{array}$ & $\begin{array}{l}22.9 \\
23.8 \\
24.1 \\
25.0\end{array}$ & $\begin{array}{l}21.9 \\
23.0 \\
22.9 \\
23.2\end{array}$ & $\begin{array}{l}21.9 \\
22.7 \\
22.3 \\
23.1\end{array}$ & $\begin{array}{l}22.9 \\
23.6 \\
24.1 \\
24.1\end{array}$ \\
\hline & Rye straw & $\begin{array}{c}0 \\
75 \\
150 \\
225\end{array}$ & $\begin{array}{l}23.6 \\
24.5 \\
26.5 \\
27.5\end{array}$ & $\begin{array}{l}22.5 \\
23.6 \\
24.9 \\
27.5\end{array}$ & $\begin{array}{l}22.6 \\
24.3 \\
25.0 \\
21.7\end{array}$ & $\begin{array}{l}25.0 \\
26.2 \\
22.9 \\
23.5\end{array}$ & $\begin{array}{l}23.4 \\
24.6 \\
24.8 \\
25.0\end{array}$ \\
\hline & Brown coal & $\begin{array}{c}0 \\
75 \\
150 \\
225\end{array}$ & $\begin{array}{l}26.0 \\
25.5 \\
27.5 \\
25.7\end{array}$ & $\begin{array}{l}22.8 \\
24.0 \\
25.1 \\
25.7\end{array}$ & $\begin{array}{l}23.0 \\
23.7 \\
23.2 \\
22.5\end{array}$ & $\begin{array}{l}23.5 \\
23.2 \\
22.3 \\
23.5\end{array}$ & $\begin{array}{l}23.8 \\
24.1 \\
24.5 \\
24.3\end{array}$ \\
\hline \multicolumn{2}{|c|}{ Mean for liming } & $\begin{array}{l}\text { Without liming } \\
\text { Liming according to } 1 \mathrm{Hh} \text { of soil }\end{array}$ & $\begin{array}{l}25.0 \\
25.6\end{array}$ & $\begin{array}{l}24.1 \\
24.3\end{array}$ & $\begin{array}{l}22.8 \\
23.1\end{array}$ & $\begin{array}{l}22.8 \\
23.3\end{array}$ & $\begin{array}{l}23.7 \\
24.1\end{array}$ \\
\hline \multicolumn{2}{|c|}{ Mean for organic fertilisation } & $\begin{array}{c}\text { Without organic fertilisation } \\
\text { Rye straw } \\
\text { Brown coal }\end{array}$ & $\begin{array}{l}24.4 \\
25.8 \\
25.8\end{array}$ & $\begin{array}{l}23.4 \\
24.7 \\
24.6\end{array}$ & $\begin{array}{l}22.5 \\
23.0 \\
23.1\end{array}$ & $\begin{array}{l}22.4 \\
23.8 \\
23.1\end{array}$ & $\begin{array}{l}23.2 \\
24.3 \\
24.1\end{array}$ \\
\hline \multicolumn{2}{|c|}{ Mean for doses of nickel } & $\begin{array}{c}0 \\
75 \\
150 \\
225\end{array}$ & $\begin{array}{l}23.4 \\
24.4 \\
26.6 \\
26.9\end{array}$ & $\begin{array}{l}22.2 \\
23.3 \\
24.6 \\
26.9\end{array}$ & $\begin{array}{l}22.3 \\
23.6 \\
23.4 \\
22.4\end{array}$ & $\begin{array}{l}22.9 \\
23.4 \\
23.0 \\
23.0\end{array}$ & $\begin{array}{l}22.7 \\
23.7 \\
24.4 \\
24.8\end{array}$ \\
\hline \multicolumn{3}{|c|}{ Mean for experiment } & 25.3 & 24.2 & 22.9 & 23.1 & 23.9 \\
\hline \multicolumn{3}{|c|}{$\begin{array}{c}\operatorname{LSD}_{0.05} \text { for: } \\
\text { Doses of nickel: } \\
\text { Liming: } \\
\text { Organic fertilisation: }\end{array}$} & $\begin{array}{l}\text { I cut } \\
0.203 \\
\text { n.s. } \\
\text { n.s. }\end{array}$ & $\begin{array}{l}\text { II cut } \\
0.208 \\
\text { n.s. } \\
\text { n.s. }\end{array}$ & $\begin{array}{l}\text { III cut } \\
\text { n.s. } \\
\text { n.s. } \\
\text { n.s. }\end{array}$ & $\begin{array}{l}\text { IV cut } \\
\text { n.s. } \\
\text { n.s. } \\
\text { n.s. }\end{array}$ & \\
\hline
\end{tabular}

Explanations: n.s. - no signified

in the plants harvested in the second and fourth cuts, all of the nickel amounts caused significant decreases in the phosphorus content. An influence of liming on the phosphorus content was found only in the fourth cut (in the plants harvested from the limed objects, the phosphorus content was significantly higher - by $4.3 \%$ on an average - than in the plants harvested from the objects that were not limed). Straw and brown coal caused the phosphorus content in the biomass of the plants harvested in the second and fourth cut to decrease significantly (by approximately $11 \%$ on an average).

The potassium content in the cock's-foot biomass (Table 5) was differentiated by all tested factors as well as by the harvest date. The greatest amount of potassium was found in the plants harvested in the fourth cut $\left(25.0 \mathrm{~g} \cdot \mathrm{kg}^{-1}\right.$ of dry mass $)$ and the smallest amount was in the plants harvested in the first cut (17.4 $\mathrm{g} \mathrm{kg}^{-1}$ of dry mass). This matches the results obtained by Gawel [2011], who studied the potassium content in meadow sward and found its amount in the plants increased each time the plants grew back. Introducing nickel into soil in doses of 75 and $150 \mathrm{mg} \mathrm{Ni} \cdot \mathrm{kg}^{-1}$ of soil caused significant increases in the potassium content in the test plants compared to the plants harvested from the objects where nickel was not applied, whilst nickel in a dose of $225 \mathrm{mg} \mathrm{Ni} \cdot \mathrm{kg}^{-1}$ of soil caused a small decrease in the potassium content (the first, second and fourth cut). Regardless of the harvest date, liming caused a significant decrease in the potassium content in the cock's-foot biomass 
Table 4. Phosphorus content $\left(\mathrm{g} \cdot \mathrm{kg}^{-1} \mathrm{~d} . \mathrm{m}\right.$.) in cock's-foot biomass

\begin{tabular}{|c|c|c|c|c|c|c|c|}
\hline \multirow{2}{*}{ Liming } & \multirow{2}{*}{$\begin{array}{l}\text { Organic } \\
\text { fertilisation }\end{array}$} & \multirow{2}{*}{$\begin{array}{l}\text { Doses of nickel } \\
\text { ( } \mathrm{mg} \cdot \mathrm{kg}^{-1} \text { of soil) }\end{array}$} & \multicolumn{4}{|c|}{ Cut } & \multirow{2}{*}{ Mean } \\
\hline & & & I & II & III & IV & \\
\hline \multirow{3}{*}{ Without liming } & $\begin{array}{l}\text { Without } \\
\text { organic } \\
\text { fertilisation }\end{array}$ & $\begin{array}{c}0 \\
75 \\
150 \\
225\end{array}$ & $\begin{array}{l}2.29 \\
3.32 \\
3.14 \\
2.52\end{array}$ & $\begin{array}{l}3.21 \\
2.68 \\
2.96 \\
2.30\end{array}$ & $\begin{array}{l}3.25 \\
3.13 \\
2.88 \\
3.22\end{array}$ & $\begin{array}{l}3.17 \\
3.28 \\
2.69 \\
3.17\end{array}$ & $\begin{array}{l}2.98 \\
3.10 \\
2.92 \\
2.80\end{array}$ \\
\hline & Rye straw & $\begin{array}{c}0 \\
75 \\
150 \\
225\end{array}$ & $\begin{array}{l}2.19 \\
3.64 \\
2.80 \\
2.21\end{array}$ & $\begin{array}{l}3.13 \\
2.73 \\
3.04 \\
2.20\end{array}$ & $\begin{array}{l}3.50 \\
3.17 \\
3.46 \\
3.09\end{array}$ & $\begin{array}{l}3.27 \\
3.20 \\
2.70 \\
3.17\end{array}$ & $\begin{array}{l}3.02 \\
3.18 \\
3.00 \\
2.67\end{array}$ \\
\hline & Brown coal & $\begin{array}{c}0 \\
75 \\
150 \\
225\end{array}$ & $\begin{array}{l}2.71 \\
3.21 \\
3.15 \\
2.28\end{array}$ & $\begin{array}{l}3.99 \\
3.29 \\
2.48 \\
1.89\end{array}$ & $\begin{array}{l}4.57 \\
3.78 \\
3.12 \\
2.96\end{array}$ & $\begin{array}{l}3.71 \\
3.02 \\
2.83 \\
2.97\end{array}$ & $\begin{array}{l}3.74 \\
3.32 \\
2.89 \\
2.53\end{array}$ \\
\hline \multirow{3}{*}{$\begin{array}{l}\text { Liming according } \\
\text { to } 1 \mathrm{Hh} \text { of soil }\end{array}$} & $\begin{array}{l}\text { Without } \\
\text { organic } \\
\text { fertilisation }\end{array}$ & $\begin{array}{c}0 \\
75 \\
150 \\
225\end{array}$ & $\begin{array}{l}2.92 \\
2.93 \\
2.44 \\
2.65\end{array}$ & $\begin{array}{l}3.09 \\
2.92 \\
3.72 \\
3.67\end{array}$ & $\begin{array}{l}3.47 \\
4.44 \\
3.35 \\
3.92\end{array}$ & $\begin{array}{l}4.35 \\
3.65 \\
4.53 \\
4.21\end{array}$ & $\begin{array}{l}3.46 \\
3.48 \\
3.51 \\
3.61\end{array}$ \\
\hline & Rye straw & $\begin{array}{c}0 \\
75 \\
150 \\
225\end{array}$ & $\begin{array}{l}2.43 \\
2.44 \\
2.90 \\
2.70\end{array}$ & $\begin{array}{l}2.54 \\
3.35 \\
2.23 \\
2.79\end{array}$ & $\begin{array}{l}3.03 \\
3.59 \\
2.89 \\
2.78\end{array}$ & $\begin{array}{l}2.92 \\
2.94 \\
2.93 \\
4.36\end{array}$ & \begin{tabular}{l|}
2.73 \\
3.08 \\
2.74 \\
3.16
\end{tabular} \\
\hline & Brown coal & $\begin{array}{c}0 \\
75 \\
150 \\
225\end{array}$ & $\begin{array}{l}2.80 \\
2.38 \\
3.07 \\
2.71\end{array}$ & $\begin{array}{l}2.90 \\
2.95 \\
2.47 \\
2.32\end{array}$ & $\begin{array}{l}2.70 \\
3.41 \\
3.45 \\
3.00\end{array}$ & $\begin{array}{l}3.56 \\
3.54 \\
3.69 \\
2.79\end{array}$ & $\begin{array}{l}2.99 \\
3.07 \\
3.17 \\
2.70\end{array}$ \\
\hline \multicolumn{2}{|c|}{ Mean for liming } & $\begin{array}{c}\text { Without liming } \\
\text { Liming according to } 1 \mathrm{Hh} \text { of soil }\end{array}$ & $\begin{array}{l}2.79 \\
2.70\end{array}$ & $\begin{array}{l}2.82 \\
2.91\end{array}$ & $\begin{array}{l}3.34 \\
3.34\end{array}$ & $\begin{array}{l}3.10 \\
3.62\end{array}$ & $\begin{array}{l}3.01 \\
3.14\end{array}$ \\
\hline \multicolumn{2}{|c|}{ Mean for organic fertilisation } & $\begin{array}{l}\text { Without organic fertilisation } \\
\text { Rye straw } \\
\text { Brown coal }\end{array}$ & $\begin{array}{l}2.78 \\
\\
2.66 \\
2.79\end{array}$ & $\begin{array}{l}3.07 \\
\\
2.75 \\
2.79\end{array}$ & $\begin{array}{l}3.45 \\
3.19 \\
3.37\end{array}$ & $\begin{array}{l}3.63 \\
3.19 \\
3.26\end{array}$ & $\begin{array}{l}3.23 \\
\\
2.95 \\
3.05\end{array}$ \\
\hline \multicolumn{2}{|c|}{ Mean for doses of nickel } & $\begin{array}{c}0 \\
75 \\
150 \\
225\end{array}$ & $\begin{array}{l}2.56 \\
2.99 \\
2.92 \\
2.52\end{array}$ & $\begin{array}{l}3.14 \\
2.99 \\
2.82 \\
2.53\end{array}$ & $\begin{array}{l}3.42 \\
3.59 \\
3.19 \\
3.16\end{array}$ & $\begin{array}{l}3.50 \\
3.27 \\
3.23 \\
3.45\end{array}$ & $\begin{array}{l}3.15 \\
3.21 \\
3.04 \\
2.91\end{array}$ \\
\hline \multicolumn{3}{|c|}{ Mean for experiment } & 2.75 & 2.87 & 3.34 & 3.36 & 3.08 \\
\hline \multicolumn{3}{|c|}{$\begin{array}{l}\mathrm{LSD}_{0.05} \text { for: } \\
\text { Doses of nickel: } \\
\text { Liming: } \\
\text { Organic fertilisation: }\end{array}$} & $\begin{array}{l}\text { I cut } \\
0.266 \\
\text { n.s. } \\
\text { n.s. }\end{array}$ & $\begin{array}{l}\text { II cut } \\
0.281 \\
\text { n.s. } \\
0.220\end{array}$ & $\begin{array}{l}\text { III cut } \\
\text { n.s. } \\
\text { n.s. } \\
\text { n.s. }\end{array}$ & $\begin{array}{l}\text { IV cut } \\
0.162 \\
0.086 \\
0.207\end{array}$ & \\
\hline
\end{tabular}

Explanations: n.s. - no signified

by $12.6 \%$ on an average, which confirms the results obtained in previous studies [Kalembasa et al. 2014]. The influence of waste organic materials on the potassium content was differential. The plants harvested from the objects where rye straw was used had a greater potassium content (by $3 \%$ on an average), and in the plants harvested from the objects where brown coal was used, the potassium content was smaller (by $12 \%$ on an average) compared to the plants harvested from the objects where organic materials were not used.

Based on the conducted pot culture experiment and the performed chemical analyses, nickel contamination in the soil, regardless of the amount of nickel, caused a significant decrease in the total yield of cock's-foot and increased its mean nitrogen and potassium contents, without differentiating its phosphorus content to a statistically significant degree. The negative influence of adding nickel to soil on the yield of the test plants was also found by other authors [Molas 2000, Spiak et al. 2003]. KoszelnikLeszek and Spiak [2006] also researched the macroelements' contents in the experimental plants depending on the differences in the nickel amount in soil, and they found that the influence of nickel on the nitrogen, phosphorus and potassium contents was not clear. Different results were obtained by Wyszkowski [2004], who found that an increase in the nickel content in soil increased the nitrogen, phosphorus and potassium contents in 
Table 5. Potassium content $\left(\mathrm{g} \cdot \mathrm{kg}^{-1} \mathrm{~d}\right.$.m.) in cock's-foot biomass

\begin{tabular}{|c|c|c|c|c|c|c|c|}
\hline \multirow[b]{2}{*}{ Liming } & \multirow[b]{2}{*}{$\begin{array}{c}\text { Organic } \\
\text { fertilization }\end{array}$} & \multirow[b]{2}{*}{$\begin{array}{l}\text { Doses of nickel } \\
\text { (mg } \mathbf{k g}^{-1} \text { of soil) }\end{array}$} & \multicolumn{4}{|c|}{ Cut } & \multirow[b]{2}{*}{ Mean } \\
\hline & & & I & II & III & IV & \\
\hline \multirow{3}{*}{ Without liming } & $\begin{array}{l}\text { Without } \\
\text { organic } \\
\text { fertilisation }\end{array}$ & $\begin{array}{c}0 \\
75 \\
150 \\
225\end{array}$ & $\begin{array}{l}18.1 \\
27.3 \\
24.2 \\
16.0\end{array}$ & $\begin{array}{l}27.1 \\
26.1 \\
26.9 \\
16.1\end{array}$ & $\begin{array}{l}20.6 \\
19.3 \\
24.1 \\
22.4\end{array}$ & $\begin{array}{l}26.1 \\
26.8 \\
24.7 \\
22.2\end{array}$ & $\begin{array}{l}21.8 \\
24.9 \\
25.0 \\
19.2\end{array}$ \\
\hline & Rye straw & $\begin{array}{c}0 \\
75 \\
150 \\
225\end{array}$ & $\begin{array}{l}17.8 \\
28.7 \\
17.9 \\
12.9\end{array}$ & $\begin{array}{l}26.3 \\
26.1 \\
27.9 \\
18.1\end{array}$ & $\begin{array}{l}31.4 \\
28.9 \\
33.1 \\
26.5\end{array}$ & $\begin{array}{l}29.2 \\
29.4 \\
28.7 \\
28.1\end{array}$ & $\begin{array}{l}26.2 \\
28.3 \\
26.9 \\
21.4\end{array}$ \\
\hline & Brown coal & $\begin{array}{c}0 \\
75 \\
150 \\
225\end{array}$ & $\begin{array}{l}13.7 \\
18.0 \\
20.8 \\
18.3\end{array}$ & $\begin{array}{l}24.6 \\
27.5 \\
22.7 \\
11.5\end{array}$ & $\begin{array}{l}21.6 \\
26.2 \\
27.4 \\
23.0\end{array}$ & $\begin{array}{l}21.7 \\
23.9 \\
23.8 \\
21.6\end{array}$ & $\begin{array}{l}20.4 \\
23.9 \\
23.7 \\
18.6\end{array}$ \\
\hline \multirow{3}{*}{$\begin{array}{l}\text { Liming according } \\
\text { to } 1 \mathrm{Hh} \text { of soil }\end{array}$} & $\begin{array}{l}\text { Without } \\
\text { organic } \\
\text { fertilisation }\end{array}$ & $\begin{array}{c}0 \\
75 \\
150 \\
225\end{array}$ & $\begin{array}{l}13.3 \\
16.4 \\
13.4 \\
21.8\end{array}$ & $\begin{array}{l}16.7 \\
17.9 \\
20.9 \\
25.6\end{array}$ & $\begin{array}{l}25.4 \\
27.0 \\
26.3 \\
29.0\end{array}$ & $\begin{array}{l}30.2 \\
27.0 \\
27.5 \\
25.6\end{array}$ & $\begin{array}{l}21.4 \\
22.1 \\
22.0 \\
25.5\end{array}$ \\
\hline & Rye straw & $\begin{array}{c}0 \\
75 \\
150 \\
225\end{array}$ & $\begin{array}{l}12.6 \\
12.1 \\
19.0 \\
19.9\end{array}$ & $\begin{array}{l}18.1 \\
23.8 \\
17.3 \\
23.3\end{array}$ & $\begin{array}{l}18.8 \\
22.4 \\
25.0 \\
25.8\end{array}$ & $\begin{array}{l}20.8 \\
25.6 \\
27.6 \\
24.7\end{array}$ & $\begin{array}{l}17.6 \\
21.0 \\
22.2 \\
23.4\end{array}$ \\
\hline & Brown coal & $\begin{array}{c}0 \\
75 \\
150 \\
225\end{array}$ & $\begin{array}{l}13.5 \\
10.0 \\
15.1 \\
16.0\end{array}$ & $\begin{array}{l}16.5 \\
16.8 \\
16.4 \\
15.4\end{array}$ & $\begin{array}{l}15.4 \\
20.2 \\
25.2 \\
25.2\end{array}$ & $\begin{array}{l}22.2 \\
21.9 \\
25.3 \\
19.6\end{array}$ & $\begin{array}{l}16.9 \\
17.2 \\
20.5 \\
19.0\end{array}$ \\
\hline \multicolumn{2}{|c|}{ Mean for liming } & $\begin{array}{c}\text { Without liming } \\
\text { Liming according to } \\
1 \mathrm{Hh} \text { of soil }\end{array}$ & $\begin{array}{l}19.5 \\
15.3\end{array}$ & $\begin{array}{l}23.4 \\
19.1\end{array}$ & $\begin{array}{l}25.4 \\
23.8\end{array}$ & $\begin{array}{l}25.1 \\
24.8\end{array}$ & $\begin{array}{l}23.3 \\
20.7\end{array}$ \\
\hline \multicolumn{2}{|c|}{ Mean for organic fertilisation } & $\begin{array}{l}\text { Without organic } \\
\text { fertilisation } \\
\text { Rye straw } \\
\text { Brown coal }\end{array}$ & $\begin{array}{l}18.8 \\
17.6 \\
15,7\end{array}$ & $\begin{array}{l}22.2 \\
22.6 \\
18.9\end{array}$ & $\begin{array}{l}24.3 \\
26.5 \\
23.0\end{array}$ & $\begin{array}{l}25.7 \\
26.8 \\
22.5\end{array}$ & $\begin{array}{l}22.7 \\
23.4 \\
20.0\end{array}$ \\
\hline \multicolumn{2}{|c|}{ Mean for doses of nickel } & $\begin{array}{c}0 \\
75 \\
150 \\
225\end{array}$ & $\begin{array}{l}14.8 \\
18.8 \\
18.5 \\
17.5\end{array}$ & $\begin{array}{l}21.5 \\
23.0 \\
22.0 \\
18.3\end{array}$ & $\begin{array}{l}22.2 \\
24.0 \\
26.8 \\
25.3\end{array}$ & $\begin{array}{l}24.3 \\
25.8 \\
26.3 \\
23.6\end{array}$ & $\begin{array}{l}20.7 \\
22.9 \\
23.4 \\
21.2\end{array}$ \\
\hline \multicolumn{3}{|c|}{ Mean for experiment } & 17.4 & 21.2 & 24.6 & 25.0 & 22.0 \\
\hline \multicolumn{3}{|c|}{$\begin{array}{c}\text { LSD }_{0.05} \text { for: } \\
\text { Doses of nickel: } \\
\text { Liming: } \\
\text { Organic fertilisation: }\end{array}$} & $\begin{array}{l}\text { I cut, } \\
1.159 \\
0.613 \\
0.909\end{array}$ & $\begin{array}{l}\text { II cut, } \\
3.034 \\
1.605 \\
2.379\end{array}$ & $\begin{array}{l}\text { III cut, } \\
2.870 \\
1.519 \\
2.251\end{array}$ & $\begin{array}{l}\text { IV cut, } \\
1.237 \\
\text { n.s. } \\
0.970\end{array}$ & \\
\hline
\end{tabular}

Explanations: n.s. - no signified

the test plants. Liming caused a significant increase in the yield of cock's-foot and decreased its potassium content, without clearly differentiating its nitrogen and phosphorus content.

The increase in the yield because of the changes in $\mathrm{pH}$ caused by liming is probably connected with nickel immobilisation in soil, as the effect of this procedure was most noticeable in the objects where $225 \mathrm{Ni} \cdot \mathrm{kg}^{-1}$ of soil was used. This matches the results obtained by Rogoża [2002].

The use of organic materials (rye straw and brown coal from a coal mine in Turów) differentiated only the phosphorus and potassium content in the test plant biomass. Both organic materials caused a decrease in the phosphorus content, and brown coal also caused a decrease in the potassium content, whilst straw caused a small increase in the potassium content. The lack of influence of straw or brown coal on the cock's-foot yield and nitrogen content may be explained by being introduced to the soil four years earlier.

Thus, liming was the main factor which limited the 'phytotoxic' influence of large amounts of nickel in the soil on the yield and chemical composition of cock's-foot. 


\section{CONCLUSIONS}

1. Introducing nickel into the soil, regardless of its amount, caused a significant decrease in the total yield of cock's-foot and increased its mean nitrogen and potassium contents.

\section{REFERENCES}

BOYD R.S., DAVIS M.A. 2001. Metal tolerance and accumulation ability of the In hyperaccumulator Streptanthus polygaloides Gray (Brassicaceae). Int. J. Phytorem. 3: 353-367.

FALKOWSKI M., KUKUŁKA L., KOZŁOWSKI S. 2000. Właściwości chemiczne roślin łąkowych. Wyd. AR w Poznaniu: 41-97.

GAWEŁ E. 2011. Skład granulometryczny i mineralny mieszanek motylkowato-trawiastych w ekologicznej i kośnopastwiskowym użytkowaniu. Pol. J. of Agronomy 6: 17-26.

KALEMBASA S., KUZIEMSKA B., KALEMBASA D., POPEK M., 2014. Wpływ wapnowania i dodatku materiałów organicznych na plonowanie oraz zawartość azotu, fosforu i siarki w biomasie kupkówki pospolitej (Dactylis glomerata L.), uprawianej w warunkach zróżnicowanej zawartości niklu w glebie. Acta Agroph. 21, 1: 35-50.

KASZUBKIEWICZ J., KAWAŁKO D. 2009. Zawartość wybranych metali ciężkich $w$ glebach i roślinach na terenie powiatu jeleniogórskiego. Och. Środ. i Zasobów Nat. 40: 177-189.

KOBIERSKI M. 2013. Evaluation of the total concentration of iron, manganese, cadmium and nickel and their dtpa extractable forms in the common dandelion rhizospheric and non-rhizospheric soil of the lower Vistula river floodplain grasslands. Och. Środ. i Zasobów Nat. 24, 3(57): 19-24, DOI 10.2478/oszn-2013-0030.

KOSZELNIK-LESZEK A., SPIAK Z. 2006. Zawartość makroskładników w roślinach doświadczalnych w zależności od poziomu niklu w glebie. Zesz. Nauk. UP Wrocław, Rolnictwo LXXXIX, 546: 125-131.

KUZIEMSKA B., KALEMBASA D., KALEMBASA S. 2014. Wpływ wapnowania i dodatku materiałów organicznych na zawartość wybranych metali w kupkówce pospolitej uprawianej na glebie zanieczyszczonej niklem. Acta Agroph. 21, 3: 293-304.
2. Soil liming caused an increase in the yield of cock's-foot and decreased its potassium content.

3. The used organic materials (straw and brown coal) caused a decrease in the phosphorus content (mean for cuts) in the grass biomass.

MOLAS J. S. 2000. Pobieranie niklu przez rośliny kapusty (Brassica oleracea L.) i jego fitotoksyczność w zależności od formy chemicznej dodanej do podłoża Zesz. Nauk. UP w Lublinie, 341.

NOGALSKA A., CZAPLA J. 2010. Plonowanie i skład mineralny kupkówki pospolitej (Dactylis glomerata L.) po zastosowaniu mączki mięsno-kostnej. Zesz. Probl. Post. Nauk Roln. 556: 193-201.

OCIEPA-KUBICKA A., OCIEPA E. 2012. Toksyczne oddziaływanie metali ciężkich na rośliny, zwierzęta i ludzi. Inż. Ochrona Środ. 15, 2: 169-180 .

ROGÓŻ A. 2002. Zawartość i pobranie pierwiastków śladowych przez rośliny przy zmiennym odczynie gleby. Zesz. Probl. Post. Nauk Roln. 482: 453-465.

SHEORAN I., SINGAL H., SINGH R. 1990.Effect of cadmium and nickel on photosynthesis and enzymes of the photosynthetic carbon reduction cycle in the pigeon pea (Cajanus cajan). Photosynth. Res. 23: 345-351.

SMOLIŃSKA B., KRÓL K. 2011. Wymywalność niklu z prób glebowych aglomeracji łódzkiej. 2001. Och. Środ. i Zasobów Nat. 49: 228-239.

SPIAK Z., ROMANOWSKA M., RADOŁA J. 2003. Effects of dose and form of nitrogen on nickel uptake by maize. Part II. Content and uptake of nickel, Chem. Inż. Ekol. 10, 9: 667-673.

WIECHUŁA D., LOSKA K., JONDERKO W. 2012. Ocena zanieczyszczenia niklem pokrzywy zwyczajnej (Urtica Dioica L.) $\mathrm{z}$ terenu województwa śląskiego. Bromat. Chem. Toksykol. XLV, 1: 20-25.

WYSZKOWSKI M. 2004. Effect of soil contamination with nickel and magnesium on the ionic ratios between macroelements in yellow lupine. Chem. Inż. Ekol. 11, 8: 833-839. 